\title{
Effects of phytogenic substances on growth performance, digestibility of nutrients, faecal noxious gas content, blood and milk characteristics and reproduction in sows and litter performance
}

\author{
Q. Wang, H.J. Kim, J. H. Cho, Y.J. Chen, J.S. Yoo. B.J. Min, \\ Y. Wang and I.H. Kim ${ }^{1}$ \\ Department of Animal Resource and Science, Dankook University \\ \#29 Anseodong, Cheonan, Choognam, 330-714, Korea
}

(Received 2 February 2007; revised version 14 November 2007; accepted 15 January 2008)

\begin{abstract}
Forty sows (Landrace×Yorkshire), with an average body weight (BW) of $184.5 \mathrm{~kg}$ and average parity of 2.65, were used to determine the effects of a phytogenic feed additive (PFA) on growth performance, digestibility of nutrients, faecal $\mathrm{NH}_{3}-\mathrm{N}$ gas content, blood and milk characteristics and litter performance. Dietary treatments included: 1. control (CON) and 2. PFA (basal diet $+0.04 \%$ phytogenic feed additive). Digestibility of dry matter $(\mathrm{DM})$ was increased significantly $(\mathrm{P}<0.05)$ in PFA treatment. Faecal ammonia nitrogen $\left(\mathrm{NH}_{3}-\mathrm{N}\right)$ measured at the end of experiment was reduced $(\mathrm{P}<0.05)$, however no significant effect $(\mathrm{P}>0.05)$ was observed on the digestibility of protein in PFA. On day 1 of lactation, albumin and lymphocyte were decreased $(\mathrm{P}<0.05)$ whereas WBC was increased significantly $(\mathrm{P}<0.05)$ when sows were fed the PFA diet. IgG content in milk was increased by PFA at farrowing and after farrowing $12 \mathrm{~h}(\mathrm{P}<0.01 ; \mathrm{P}<0.05)$. Similarly, IgA content in milk was increased by PFA after farrowing $12 \mathrm{~h}(\mathrm{P}<0.01)$. Protein and solid concentration in colostrum were significant lower $(\mathrm{P}<0.01 ; \mathrm{P}<0.05)$ in PFA treatment than CON treatment after farrowing $12 \mathrm{~h}$. In conclusion, feeding $0.04 \%$ of PFA from day 107 of gestation to day 21 of lactation improved DM digestibility, RBC and WBC concentration, and lactose, IgG and IgA production in colostrums and decreased faecal $\mathrm{NH}_{3}-\mathrm{N}$ concentration.
\end{abstract}

KEY WORDS: phytogenic feed additives, performance, blood chemistry, milk, sows

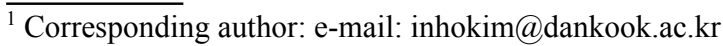




\section{INTRODUCTION}

The use of antibiotics as growth promoters in animal feeds is facing reduced social acceptance due to the appearance of residues and resistant strains of bacteria (Gustafson and Bowen, 1997). The use of antibiotics has been prohibited in the European Union since January 2006 (Regulation 1831/2003/EC). Natural, safe and inexpensive feed additives that do not endanger the environment with residues in wastes should be developed. It is noteworthy that there is a revival of phytogenic feed additives in the world, as a successful alternative to the prophylactic use of antibiotics against pig dysentery (Bilkei, 1995). Phytogenic feed additive (PFA) influenced positively daily feed intake, daily weight gain, and feed utilization in growing pigs and improved growth performance in pigs (Gunter and Bossow, 1998; Baumann et al., 2003).

Our study was concerned on one of PFA products named Fresta F Conc ${ }^{\circledR}$ (Delacon Co., Ltd, Steyregg, Austria). The product is made of essential oils, flavonoids, pungent substances, and mucliages. Major components consist of up to $40 \%$ of the essential oil. Essential oils are aromatic oily liquids obtained from plant material (flowers, buds, seeds, leaves, twigs, bark, herbs, woods, fruits, and roots). Most of essential oils are classified as Generally Recognized as Safe (GRAS), and have been approved for food and beverage consumption by the United States Food and Drug Administration.

The objective of the current experiment was to determine whether additional PFA during late-gestation (day 107) and lactation would affect sow and litter. The hypothesis was that the antibacterial, appetite enhancing ability of PFA would increase sow's performance, improve sow's immunity, decrease excretion of nutrients, ameliorate milk characteristics and have effect on reproduction parameters.

\section{MATERIAL AND METHODS}

\section{Experimental design and measurements}

The experimental protocol was approved by the Animal Care and Use Committee of Dankook University. A total of forty (Landrace $\times$ Yorkshire) sows, with an average body weight of $184.5 \mathrm{~kg}$ (from 150.7 to $220.5 \mathrm{~kg}$ ) and average parity 2.65 (from 1 to 4), were used for this experiment in each treatment of twenty sows. Experimental treatments were as follows: 1. control (CON), basal diet), and 2. PFA (basal diet $+0.04 \%$ phytogenic feed additive). Phytogenic feed additive was replaced with maize in the diets. Experimental diets were fed from day 107 of gestation to day 21 of lactation except at the day of parturition. On day 107 of ge- 
station, sows were placed in an environmentally regulated farrowing facility until weaning (day 21). Temperature was maintained at a maximum of $20^{\circ} \mathrm{C}$. Sows were housed in farrowing crates $(2.1 \times 0.6 \mathrm{~m})$ with an area $(2.1 \times 0.6 \mathrm{~m})$ on either side of the crate for the piglets. Before farrowing, rubber mats were put down as surface for piglets to lie on. Heat lamp was suspended above each rubber mat to keep the temperature for newborn piglets constant at $35^{\circ} \mathrm{C}$.

Sows were fed $2 \mathrm{~kg}$ of experimental diets (\%: total lysine $0.9, \mathrm{Ca} 0.8$ and $\mathrm{P}$ 0.7 ; Table 1) with or without $0.04 \%$ of added PFA to allow for adaptation to the diets before parturition. On the day of parturition, the sows were not offered feed.

Table 1. Formula and chemical composition of experimental diet, as fed basis

\begin{tabular}{|c|c|c|}
\hline Item & $\mathrm{CON}^{1}$ & $\mathrm{PFA}^{2}$ \\
\hline \multicolumn{3}{|l|}{ Ingredients, $\%$} \\
\hline maize & 53.95 & 53.91 \\
\hline soyabean meal & 20.40 & 20.40 \\
\hline tallow & 5.00 & 5.00 \\
\hline wheat & 4.00 & 4.00 \\
\hline lupin seed meal & 4.00 & 4.00 \\
\hline wheat bran & 3.69 & 3.69 \\
\hline molasses & 3.00 & 3.00 \\
\hline canola meal & 3.00 & 3.00 \\
\hline tricalcium phosphate & 1.95 & 1.95 \\
\hline salt & 0.40 & 0.40 \\
\hline limestone & 0.13 & 0.13 \\
\hline lysine & 0.11 & 0.11 \\
\hline choline chloride & 0.11 & 0.11 \\
\hline vitamin/mineral premix ${ }^{3}$ & 0.20 & 0.20 \\
\hline antibiotics $^{4}$ & 0.06 & 0.06 \\
\hline phytogenic feed additive & - & 0.04 \\
\hline \multicolumn{3}{|l|}{ Chemical composition $^{5}$} \\
\hline $\mathrm{ME}, \mathrm{MJ} / \mathrm{kg}^{6}$ & 14.20 & 14.20 \\
\hline crude protein, $\%$ & 16.60 & 16.60 \\
\hline lysine, $\%$ & 0.90 & 0.90 \\
\hline calcium, $\%$ & 0.80 & 0.80 \\
\hline phosphorus, \% & 0.70 & 0.70 \\
\hline
\end{tabular}

${ }^{1}$ abbreviations CON, basal diet; PFA, basal diet added $0.04 \%$ phytogenic feed additive

${ }^{2}$ pooled standard error

${ }^{3}$ supplied per kg diet, IU: vit. A 11.025; vit. $\mathrm{D}_{3} 11.103$; vit. E 44; mg: vit. K (menadione bisulfate complex) 4.4; riboflavin 8.3; niacin 50; d-pantothenic acid (d-calcium pantothenate) 29; choline 166; $\mu$ g: vit. $\mathrm{B}_{12}$ 33; mg: $\mathrm{Cu} 16$; Fe 165; Zn 165; Mn 12; I 0.3; Co 1.0 and Se 0.3

${ }^{4}$ supplied $100 \mathrm{mg}$ of chlortetracycline per $\mathrm{kg}$ of complete diet

${ }^{5}$ calculated values

${ }^{6}$ ME-based on dry matter 
From day 1 of lactation, sows were allowed ad libitum access to feed and water, and feed intake was recorded weekly and average daily feed intake (ADFI) was calculated.

Backfat thickness was measured at last rib $(65 \mathrm{~mm}$ from the center line of the back) using real-time ultrasound (Piglog105, version 3.1, Denmark). Values from the two measurements were averaged to obtain a single backfat measurement. Backfat thickness was measured on day 0 and 21 after farrowing. During experimental period, individual numbers of piglets alive and death per litter were recorded. Individual pig weight was recorded at birth and weaning to determine weight gain. After weaning, sows were transferred to pens adjacent to mature boars and were directly exposed to boars twice a day for oestrus detection.

During the lactation, chromium oxide $(0.20 \%)$ was used as an indigestible marker to calculate digestibility coefficients. At the end of lactation period, faecal samples were taken from each sow to determine the digestibility of DM and nitrogen. All the faecal samples, as well as feed samples were stored in refrigerator until analysis. Before chemical analysis, faecal samples were thawed and dried at $70^{\circ} \mathrm{C}$ for $72 \mathrm{~h}$ and subsequently ground to pass through a $1-\mathrm{mm}$ screen. All the feed and faecal samples were analysed for DM and N according to AOAC (1995), while chromium was determined by UV absorption spectrophotometry (Shimadzu, IJV-1201, Japan) according to Fenton and Fenton (1979). Nitrogen was measured using a Kjeltec 2300 Analyzer (Foss Tecator AB, Hoeganaes, Sweden). Faecal $\mathrm{NH}_{3}-\mathrm{N}$ concentration was determined according to the method of Chaney and Marbach (1962).

Within $6 \mathrm{~h}$ after farrowing, ten sows were randomly chosen from each treatment and blood samples were collected from cervical vein into both $\mathrm{K}_{3}$ EDTA vacuum tubes and clot activator vacuum tubes (Becton Dickinson Vacutainer Systems, Franklin Lakes, NJ, USA) immediately and stored in refrigerator at $-4^{\circ} \mathrm{C}$. The same sows were bled again on day 1 and day 21 of lactation. The blood cell counts (WBC, RBC and lymphocyte) were analysed by the automatic blood analyser (ADVIA 120, Bayer, NY). Samples for serum analysis were centrifuged at $3.000 \mathrm{~g}$ for $15 \mathrm{~min}$ and serum was separated. Total protein, albumin and IgG concentrations in serum were determined by the automatic biochemistry analyser (HITACHI 747, Japan).

Furthermore, approximately 30 to $40 \mathrm{ml}$ of colostrum was collected from functional glands of these sows within $12 \mathrm{~h}$ from termination of farrowing. On day 1 and 21 of lactation, 30 to $40 \mathrm{ml}$ of mature milk was collected. The colostrum and milk samples obtained were analysed for concentrations of fat, protein, lactose, solids, IgG and and IgA. Milk fat, protein, lactose and solids were analysed by a commercial laboratory using a Milkoscan System 4000 (Foss North America, Eden Prairie, MN; AOAC, 1990). The concentrations of immunoglobulins (IgG, IgA) were determined by radial immunodiffusion (Mancini et al., 1965). 


\section{Statistical analysis}

In this experiment, sow was considered the experimental unit. Data were analysed using the GLM procedure of SAS (1996). Farrowing group was used as a block. The analysis of sow backfat thickness and change during lactation used fat depth at farrowing as covariates. Piglet birth weight was used as covariates for weaning weights during lactation. Lactation length was used as a covariate for number of pigs weaned, survivability, sows and piglets weaning weights, sows ADFI, and return of oestrus and backfat thickness depth change. Variability of all the data was expressed as standard error (SE) and a probability level of $\mathrm{P}<0.05$ was considered as statistically significant.

\section{RESULTS}

Growth performance of sows and piglets. There was no significant difference in ADFI between dietary treatments (Table 2). Neither backfat loss nor return of

Table 2. Effect of phytogenic feed additive on growth performance in sows

\begin{tabular}{lcccc}
\hline Items & $\mathrm{CON}^{1}$ & $\mathrm{PFA}^{1}$ & $\mathrm{SE}^{2}$ & $\mathrm{P}^{3}$ \\
\hline Number of sows & 20 & 20 & - & - \\
Average parity & 2.50 & 2.75 & 0.09 & $\mathrm{NS}$ \\
& & & & \\
Sow backfat thickness, mm & & & & $\mathrm{NS}$ \\
$\quad$ farrowing & 31.40 & 29.60 & 1.30 & $\mathrm{NS}$ \\
$\quad \mathrm{d} 21$ of lactation & 24.60 & 24.95 & 0.81 & $\mathrm{NS}$ \\
ADFI, kg & 5.43 & 5.48 & 0.08 & $\mathrm{NS}$ \\
Return of oestrus, day & 5.55 & 5.35 & 0.19 & \\
\hline
\end{tabular}

${ }^{1}$ see Table 1

${ }^{2}$ pooled standard error

${ }^{3} \mathrm{NS}$ - not significant

Table 3. Effect of phytogenic feed additive on growth performance in litters

\begin{tabular}{lcccc}
\hline Items & $\mathrm{CON}^{1}$ & $\mathrm{PFA}^{1}$ & $\mathrm{SE}^{2}$ & $\mathrm{P}^{3}$ \\
\hline $\begin{array}{l}\text { Average piglet weight, } \mathrm{kg} \\
\text { birth }\end{array}$ & 1.65 & 1.65 & 0.06 & $\mathrm{NS}$ \\
$\quad$ weaning & 5.89 & 6.30 & 0.18 & $\mathrm{NS}$ \\
$\quad \begin{array}{l}\text { Number of pigs per litter } \\
\text { birth }\end{array}$ & 10.7 & 10.2 & & \\
$\quad$ weaning & 10.0 & 9.9 & 0.6 & $\mathrm{NS}$ \\
Pig survivability,\% & 93.5 & 96.8 & 0.5 & $\mathrm{NS}$ \\
\end{tabular}

${ }^{1}$ see Table 1

${ }^{2}$ pooled standard error

${ }^{3} \mathrm{NS}$ - not significant 
oestrus differed in dietary treatments $(\mathrm{P}>0.05)$. No differences $(\mathrm{P}>0.05)$ were observed on average piglet weight at weaning. Number of pigs per litter and pig survival were not affected by dietary treatment $(\mathrm{P}>0.05)$.

Digestibility and faecal $\mathrm{NH}_{3}-\mathrm{N}$ content. During the experimental period, digestibility of $\mathrm{DM}$ was increased $(\mathrm{P}<0.05)$ by dietary supplementation with $0.04 \%$ PFA (Table 4 ). There was no significant difference in digestibility of nitrogen between the treatments.

Table 4. Effect of phytogenic feed additive on digestibility of nutrients in sows

\begin{tabular}{lllll}
\hline Digestibility, \% & $\mathrm{CON}^{1}$ & $\mathrm{PFA}^{1}$ & $\mathrm{SE}^{2}$ & $\mathrm{P}^{3}$ \\
\hline Dry matter & 76.35 & 80.00 & 0.39 & $* *$ \\
Nitrogen & 78.69 & 80.67 & 1.20 & NS \\
\hline
\end{tabular}

${ }^{1}$ see Table 1

${ }^{2}$ pooled standard error

${ }^{3} \mathrm{NS}$ - not significant, $* * \mathrm{P}<0.01$

Table 5 shows the effect PFA on faecal $\mathrm{NH}_{3}-\mathrm{N}$ concentration in sows. On day 1, 2 and 4, no statistical differences $(\mathrm{P}>0.05)$ were found in $\mathrm{NH}_{3}-\mathrm{N}$ concentration between treatments. On day $7, \mathrm{NH}_{3}-\mathrm{N}$ concentration in sows fed PFA diet was lower than sows fed CON diet $(\mathrm{P}<0.05)$.

Table 5. Effect of phytogenic feed additive on faecal $\mathrm{NH}_{3}-\mathrm{N}$ concentration in sows

\begin{tabular}{lcccc}
\hline $\mathrm{NH}_{3}-\mathrm{N}, \mathrm{ppm}$ & $\mathrm{CON}^{1}$ & $\mathrm{PFA}^{1}$ & $\mathrm{SE}^{2}$ & $\mathrm{P}^{3}$ \\
\hline 1 day & 0.00 & 0.00 & 0.00 & - \\
2 days & 0.56 & 0.00 & 0.22 & $\mathrm{NS}$ \\
4 days & 1.62 & 0.90 & 0.83 & $\mathrm{NS}$ \\
7 days & 8.12 & 3.70 & 0.51 & $* *$ \\
\hline
\end{tabular}

${ }^{1}$ see Table 1

${ }^{2}$ pooled standard error

${ }^{3} \mathrm{NS}$ - not significant, ${ }^{* *} \mathrm{P}<0.01$

Blood characteristics. No significant differences were observed for total protein, albumin, IgG, RBC, WBC, lymphocyte concentrations at farrowing $(\mathrm{P}>0.05$; Table 6$)$. On day 1 of lactation, albumin and lymphocyte contents were decreased $(\mathrm{P}<0.05)$, whereas WBC content was increased when sows were fed the diet with $0.04 \%$ PFA. On day 21 of lactation, RBC and WBC were increased significantly $(\mathrm{P}<0.05)$ in PFA treatment compared with $\mathrm{CON}$ treatment. 
Table 6. Effect of phytogenic feed additive on blood characteristics in sows

\begin{tabular}{|c|c|c|c|c|}
\hline Items & $\mathrm{CON}^{1}$ & PFA $^{1}$ & $\mathrm{SE}^{2}$ & $\mathrm{P}^{3}$ \\
\hline \multicolumn{5}{|c|}{ Total protein, $\mathrm{g} / \mathrm{dl}$} \\
\hline farrowing & 7.04 & 6.77 & 0.09 & NS \\
\hline 1 day & 7.13 & 6.94 & 0.11 & NS \\
\hline 21 days & 7.13 & 7.37 & 0.08 & NS \\
\hline \multicolumn{5}{|c|}{ Albumin, $g / d l$} \\
\hline farrowing & 4.30 & 4.31 & 0.09 & NS \\
\hline 1 day & 4.39 & 4.19 & 0.05 & $*$ \\
\hline 21 days & 4.06 & 4.19 & 0.07 & NS \\
\hline \multicolumn{5}{|l|}{$\operatorname{Ig} G, m g / d l$} \\
\hline farrowing & 640.14 & 560.71 & 24.10 & NS \\
\hline 1 day & 692.14 & 617.71 & 32.12 & NS \\
\hline 21 days & 850.57 & 927.71 & 62.70 & NS \\
\hline \multicolumn{5}{|c|}{$R B C, 10^{6}, \mathrm{No} . / \mathrm{mm}^{3}$} \\
\hline farrowing & 5.37 & 5.66 & 0.11 & NS \\
\hline 1 day & 6.16 & 6.75 & 0.22 & NS \\
\hline 21 days & 6.04 & 8.98 & 0.14 & $*$ \\
\hline \multicolumn{5}{|c|}{$W B C, 10^{4}$, No. $/ \mathrm{mm}^{3}$} \\
\hline farrowing & 14.26 & 12.53 & 1.38 & NS \\
\hline 1 day & 13.36 & 15.25 & 0.65 & $*$ \\
\hline 21 days & 13.80 & 16.67 & 1.17 & * \\
\hline \multicolumn{5}{|c|}{ Lymphocyte, \% } \\
\hline farrowing & 21.00 & 22.29 & 2.19 & NS \\
\hline 1 day & 40.57 & 22.00 & 3.61 & $* *$ \\
\hline 21 days & 39.43 & 37.00 & 3.75 & NS \\
\hline
\end{tabular}

${ }^{1}$ see Table 1

${ }^{2}$ pooled standard error

${ }^{3} \mathrm{NS}$ - not significant, $* \mathrm{P}<0.05$

Milk characteristics. Immunoglobulin G concentration was increased in PFA treatment at farrowing $(\mathrm{P}<0.05$; Table 7$)$. When sows were fed PFA diet, milk protein and solid concentration were significantly lower in colostrum (12 h) than basal diet $(\mathrm{P}<0.05)$, however no differences were observed in milk (day 21) between treatments $(\mathrm{P}>0.05)$. Obtained data show an increase $(\mathrm{P}<0.05)$ in lactose, $\mathrm{IgG}$ and $\mathrm{IgA}$ in colostrum in PFA treatments. 
Table 7. Effect of phytogenic feed additive on milk characteristics in sows

\begin{tabular}{|c|c|c|c|c|}
\hline Items & $\mathrm{CON}^{1}$ & $\mathrm{PFA}^{1}$ & $\mathrm{SE}^{2}$ & $\mathrm{P}^{3}$ \\
\hline \multicolumn{5}{|l|}{ Fat, \% } \\
\hline farrowing & 5.11 & 4.49 & 0.34 & NS \\
\hline $12 \mathrm{~h}$ & 4.28 & 5.12 & 0.26 & NS \\
\hline 21 days & 6.97 & 7.53 & 0.27 & NS \\
\hline \multicolumn{5}{|l|}{ Protein, \% } \\
\hline farrowing & 19.01 & 18.21 & 0.34 & NS \\
\hline $12 \mathrm{~h}$ & 17.11 & 14.50 & 0.19 & $* *$ \\
\hline 21 days & 5.05 & 5.08 & 0.05 & NS \\
\hline \multicolumn{5}{|l|}{ Lactose, $\%$} \\
\hline farrowing & 2.01 & 2.03 & 0.15 & NS \\
\hline $12 \mathrm{~h}$ & 2.12 & 2.68 & 0.06 & $* *$ \\
\hline 21 days & 5.32 & 5.36 & 0.12 & NS \\
\hline \multicolumn{5}{|l|}{ Solid, \% } \\
\hline farrowing & 26.84 & 26.30 & 0.22 & NS \\
\hline $12 \mathrm{~h}$ & 24.82 & 23.58 & 0.32 & $*$ \\
\hline 21 days & 18.74 & 19.44 & 0.29 & NS \\
\hline \multicolumn{5}{|l|}{$\mathrm{Ig} G, \mathrm{mg} / \mathrm{ml}$} \\
\hline farrowing & 133.58 & 197.83 & 14.11 & $* *$ \\
\hline $12 \mathrm{~h}$ & 103.32 & 121.40 & 4.60 & $*$ \\
\hline 21 days & 0.343 & 0.399 & 0.037 & NS \\
\hline \multicolumn{5}{|l|}{$\operatorname{Ig} A, \mathrm{mg} / \mathrm{ml}$} \\
\hline farrowing & 21.47 & 25.47 & 2.44 & NS \\
\hline $12 \mathrm{~h}$ & 13.52 & 21.40 & 1.72 & $* *$ \\
\hline 21 days & 3.072 & 2.967 & 0.274 & NS \\
\hline
\end{tabular}

${ }^{1}$ see Table 1

${ }^{2}$ pooled standard error

${ }^{3} \mathrm{NS}$ - not significant, ${ }^{*} \mathrm{P}<0.05,{ }^{* *} \mathrm{P}<0.01$

\section{DISCUSSION}

Phytogenic feed additives as growth promoters are controversially discussed in the literature (Sivropoulou et al., 1996; Tsinas et al., 1998; Khajarern and Khajarern, 2002). The positive effect of dietary essential oils on sow health and production may be because of the effects of antioxidant (Aeschbach et al., 1994), antibacterial (Didry et al., 1994), antiphlogistic (Azuma et al., 1986), and antiinflammatory (Azuma et al., 1986) effects. Khajarern and Khajarern (2002) stated that carvacrol and thymol affected the mucosal membrane in the intestines and 
accelerated the renewal rate of enterocytes on the surface intestinal villi; this would reduce pathogen attachment to enterocytes and improve nutrient absorption capacity. Furthermore, these authors stated that origanum essential oils act not only as alternative antibacterial performance promoters, digestion aids, and appetite enhancers in sows, but also as natural feed additives to enhance growth and reproductive performance in sows (Khajarern and Khajarern, 2002). In one study, feed supplementation with $1000 \mathrm{ppm}$ oregano during the prefarrowing and lactation period significantly improved weight gain of pigs (Amrik and Bilkei, 2004). When beneficial responses in litter performance from essential oils were observed, sows were fed essential oils for at least $10 \mathrm{~d}$, and usually $14 \mathrm{~d}$, prior to farrowing (Amrik and Bilkei, 2004; Mauch and Bilkei, 2004). We began feeding our experimental diets no more than $7 \mathrm{~d}$ prior to farrowing. Inconsistent results might be due to this reason.

Obtained data suggested that digestibility of DM was increased by the supplementation of PFA. Wang et al. (1999) observed that essential oils stimulated both organic matter and microbiotical digestion. Previous research (Didry et al., 1994; Tsinas et al., 1998) found that essential oils enhanced the regulation of gastrointestinal metabolism and exerted antibacterial properties in the digestive tract of pigs. Cho et al. (2006) demonstrated that $\mathrm{NH}_{3}$ concentration in faeces was significantly reduced by addition of essential oils by improving $\mathrm{N}$ digestibility. However, in our study, no improvements in $\mathrm{N}$ digestibility were noted when sows were fed on diets supplemented with PFA. Therefore, the reduction of $\mathrm{NH}_{3}-\mathrm{N}$ concentration in faeces may not be the result of increased nutrient digestibility, but rather of the alteration of intestinal microflora. In fact, Mcintosh et al. (2003) observed that a blend of essential oil compounds inhibited the growth of Clostridium sticklandii and Peptostreptococcus anaerobius which are hyperproducing ammonia species.

Pungent substances (i.e. garlic, black pepper and chilli), the active components of PFA, have activation of blood circulation and metabolic processes (Rodas, 2006). Iranloye (2002) had shown that daily feeding of rats with $200 \mathrm{mg} / \mathrm{kg}$ garlic juice increased the RBC and WBC. It is also possible that the end product of pungent substances metabolism in the body stimulates the kidney directly to cause formation and secretion of erythropoietin. The immunomodulatory effects of naturally occurring sulphur compounds in pungent substances include WBC, RBC being enhanced significantly in animals (Kuttan, 2000). The present results confirmed their findings. Albumin and lymphocyte concentrations were decreased $(\mathrm{P}<0.05)$. The exact mechanisms of this additive can not be explained clearly by current study. In the future more studies should be conducted.

Our result was in agreement with previous study by Xie et al. (1999) who found that when essential oils (leleshwa oil) were given to sows during the last week of gestation and throughout lactation, milk protein in colostrum decreased 
significantly compared with control treatment. The mechanisms by which the essential oils may be affecting milk protein are unknown. In the 6th week prior to parturition, colostrogenesis has begun. Antibodies found in the initial lacteal secretions partly (IgA) or solely (IgG) originate from the sows circulation (Watson, 1980) and a boost to serum antibodies during this period would therefore be thought to lead to an improvement in colostrum levels. Also, Mauch and Bilkei (2004) reported that essential oils (oregano) decreased populations of undesirable microorganisms and stimulated the secretion of antibodies maybe positively influenced $\operatorname{IgG}$ and IgA level in colostrum.

\section{CONCLUSIONS}

The results presented in this article should encourage the scientific community to continue investigations of phytogenic feed additives as alternatives to antibiotics. This production is effective in improving $\mathrm{WBC}, \mathrm{RBC}$ and colostrum characteristics and reducing $\mathrm{NH}_{3}-\mathrm{N}$. In contrast, $0.04 \%$ phytogenic feed additives (PFA) has no apparent effect on sows or piglets growth performance. Further research is needed to determine the optimum level of PFA needed in gestation and lactation diets.

\section{REFERENCES}

AOAC, 1990. Association of Official Analytical Chemists, Official Method of Analysis. 15th Edition. Washington, DC

AOAC, 1995. Association of Official Analytical Chemists, Official Method of Analysis.16th Edition. Washington, DC

Aeschbach R., Loliger J., Scott B.C., Murcia A., Butler J., Halliwell B., 1994. Antioxidant actions of thymol, carvacrol, 6-gingerol, zingerone and hydroxytyrosol. Food Chem. Toxicol. 32, 31-36

Amrik B., Bilkei G., 2004. Influence of farm application of oregano on performance on sow. Can. Vet. J. 45, 674-677

Azuma Y., Ozasa N., Ueda Y., Takagia N., 1986. Pharmacological studies on the antiinflammatory action of phenolic compounds. J. Dent. Res. 65, 53-56

Baumann B., Brikle G., Pinkas M., 2003. Effect of dietary oregano extract on the development of swine dysentery in a pureculture challenge model. Biol. Tiermed. 11, 296-299

Bilkei G., 1995. Herd health strategy for improving the reproductive performance of pigs. In: Proceedings of the Eighth "In-between" Symposium of the International Society for Animal Hygiene. Hung. Vet. J. 10, 766-768

Chaney A.L., Marbach E.P., 1962. Modified regents for determination of urea and ammonia. Clin. Chem. 8, 131

Cho J.H., Chen Y.J., Min B.J., Kim H.J., Kwon O.S., Shon K.S., Kim I.H., Kim S.J., Asamer A., 2006. Effect of essential oils supplementation on growth performance, IgG concentration and fecal noxious concertration of weaned pig. Asian-Austr. J. Anim. Sci. 19, 2607-2611

Didry N., Dubreuil L., Pinkas M., 1994. Activity of thymol, carvacrol, cinamaladehyd and eugenol on oral bacteria. Pharm. Acta Helv. 69, 25-28 
Gunter K.D., Bossow H., 1998. The effect of etheric oil from Origanum vulgaris (Ropadiar1) in the feed ration of weaned pigs on their daily feed intake, daily gains and food utilization. In: Proceedings of the 15th IPVS Congress, Birmingham, p. 223

Gustafson R.H., Bowen R.E., 1997. Antibiotic use in animal agriculture. J. Appl. Microbiol. 83, 531-541

Iranloye B.O., 2002. Effect of chronic garlic feeding on some haematological parameters. Afr. J. Biomed. Res. 65, 81-82

Khajarern J., Khajarern S., 2002. The efficacy of origanum essential oils in sow feed. Int. Pig Topics. 17,17

Kuttan G., 2000. Immunomodulatory effect of some naturally occuring sulphur containing compounds. J. Ethnopharmacol. 72, 93-99

Mancini G., Carbonara O.A., Heremans J.J., 1965. Immunochemical quantitation of antigens by single radial immunodiffusion. Immunochemistry 2, 235-254

Mcintosh F.M., Williams P., Losa R., Wallace R.J., Beever D.A., Newbold C.J., 2003. Effects of essential oils on animal microorganisms and their protein metabolism. Appl. Environ. Microbiol. 69, 5011-5014

Rodas D.B., 2006. The use of botanical feed additives in nursery and sow diets in the US. In: Proceedings of Delacon Performing Nature Symposium.Vienna (Austria), pp. 1-4

SAS, 1996. SAS Uer's Guide. Release 6.12 Edition. SAS Institute Inc. Cary, NC

Sivropoulou A., Papanikolaou E., Nikolaou C., 1996 Antimicrobial and cytotoxic activities of Oreganum essential oils. J. Agr. Food Chem. 44, 1202-1205

Tsinas A.C., Giannakopoulos G., Papaseriades A., 1998. Use of origanum essential oils as growth promoter in pigs. In: Proceedings of 15th IPVS Congress, Birmingham, pp. 220-222

Xie Y., Fen M.X., Li Z., Hua P., 1999. Botanical feed additive in animals. Proceedings of the 1999 Hunan Swine Industry Symposium, Hunan, Zhuzhou, pp. 38-41

Wang D., Wu F.X., Rong Y., 1999. Chinese Herbs in Animal Nutrition. Nottingham University Press, pp. 7-83

Watson D.L., 1980. Immunological functions of the mammary gland and its secretion -comparative review. Aust. J. Biol. Sci. 33, 403-422 